\title{
Çocukluk Çağı Sistemik Lupus Eritematozusunda Başlangıç Bulguları ve Tedavi:Tek Merkez Deneyimi
}

\section{Clinical Presentation and Treatment of Systemic Lupus Erythematosus in Childhood:Single Center Experience}

\author{
Semih SANDAL ${ }^{1}$, Banu ÇELIKEL ACAR²
}

'Sağlık Bilimleri Üniversitesi, Ankara Çocuk sağlığı ve Hastalıkları Hematoloji Onkoloji SUAM, Çocuk sağlığı ve Hastalıkları Kliniği, Ankara,Türkiye

${ }^{2}$ Sağlık Bilimleri Üniversitesi, Ankara Çocuk sağlığı ve Hastalıkları Hematoloji Onkoloji SUAM, Çocuk Nefroloji Kliniği, Ankara,Türkiye

\section{ÖZ}

Amaç: Sistemik lupus eritematozus (SLE), immünolojik bozuklukların yol açtığı, otoimmün karakterli, birçok organ ve sistemi tutan, kronik bir bağ dokusu hastalığıdır. Çalışmada SLE tanısı ile izlenen hastaların hastaneye başvuru yakınmalarının, klinik ve laboratuar bulgularının değerlendirilmesi amaçlanmıştır.

Gereç ve Yöntemler: Bu çalışma Ocak 2001- Ocak 2014 tarihleri arasında Çocuk Nefroloji-Romatoloji Bölümü tarafından SLE tanısı ile izlenen hastaların dosyaları ve bilgisayar kayıtları geriye dönük incelenerek yapılmıştır. Çalışmada SLE tanısı ile izlenen hastaların başvuru yakınmaları, klinik ve laboratuar bulguları ile tedavileri ve izlem süresince gelişen organ tutulumları kaydedilmiştir.

Bulgular: Çalışmaya Amerikan Romatoloji Birliği'nin (ACR) 1997 yllında yenilediği 11 SLE kriterinden 4 veya daha fazlasını karşılayan ya da böbrek biyopsisi sonucu lupus nefriti ile uyumlu bulgular saptanan 13 hasta (10'u kı, 3'ü erkek) alınmıştır. Hastaların 10'u kız (\% 76.9), 3'ü erkek (\% 23.1), kı/erkek oranı 3.3 genel yaş ortalaması 12.8 \pm 2.79 (6-17 yıl) bulundu. Hastaların ortalama izlem süresi 8.1 \pm 2.34 yıl (4-13 yıl)'dı.

Hastaneye başvuru anında hastaların 6'sında (\%46.1) yüzde döküntü, 4'ünde (\%30.7) bacaklarda ödem, 2'sinde (\%15.3) eklemlerde şişlik ve ağı, 1'inde (\%7.6) göğüs ve eklem ağrısı, 1'inde (\%7.6) solukluk şikayeti mevcuttu.

İzlemde, 2 hastada cilt, 3 hastada hematolojik, 5 hastada eklem, 1 hastada serozit/perikard tutulumu, 1 hastada nörolojik tutulum gelişti. Böbrek tutulum oranı \% 84.6 olarak bulundu. 3 hastada başvuru anında kreatinin değeri yüksekliği ve 5 hastada nefrotik düzeyde proteinüri saptandı. Başvuru anındaki proteinüri ve kreatinin ile histopatolojik inceleme sonucu arasında ilişki saptanmadı.

Sonuç: Bu çalışma ile çocukluk çağında başlayan SLE'de tanı anında birden fazla sistem ve organın tutulduğu, bu nedenle başvuru șikayetinin anemiden böbrek yetmezliğine kadar değişkenlik gösterebildiği görülmüştür. Uygun tanı ve tedavi ile morbidite ve mortalite azaltılabileceği için çocukluk çağında SLE'nin farklı klinik ve laboratuvar bulgularıyla karşımıza gelebileceği akılda tutulmalıdır.

Anahtar Sözcükler: Çocukluk çağı, Nefrit, Sistemik lupus eritematozus

\begin{abstract}
Objective: Systemic lupus erythematosus (SLE) is a chronic connective tissue disease caused by autoimmune, immunological disorders which can effect many organs and systems. The aim of this study was to evaluate the complaints, clinical and laboratory findings of patients with SLE.

Material and Methods: This study was performed between January 2001 and January 2014 by the Department of Child Nephrology-Rheumatology with the diagnosis of SLE. In this study, clinical and laboratory findings, treatment, organ involvement of the patients, who were followed up with the diagnosis of SLE, were recorded.

Results: Thirteen patients (10 girls, 3 boys) who received 4 or more of 11 SLE criteria renewed in 1997 by the American College of Rheumatology (ACR) or who had consistent findings with lupus nephritis by kidney biopsy were included in

Conflict of Interest / Çıkar Çatışması: On behalf of all authors, the corresponding author states that there is no conflict of interest.

Ethics Committee Approval / Etik Kurul Onayı: Academic committee approval for this study.

Contribution of the Authors / Yazarların katkısı: SANDAL S: Verilerin toplanması, makalenin yazımı, ÇELiKEL ACAR B: Çalıșmanın fikrinin oluşturulması ve her aşamada çalışmaya ait tüm kontrollerin yapılması.

How to cite / Atıf yazım şekli : Sandal S, Çelikel Acar B. Çocukluk Çağı Sistemik Lupus Eritematozusunda Bașlangıç Bulguları ve Tedavi:Tek Merkez Deneyimi. Turkish J Pediatr Dis 2020; 14: 225-230.
\end{abstract}

(1)
Yazışma Adresi / Correspondence Address:

Semih SANDAL

Sağlık Bilimleri Üniversitesi, Ankara Çocuk sağıı̆ı ve Hastalıkları Hematoloji Onkoloji SUAM,

Çocuk sağlığı ve Hastalıkları Kliniği, Ankara, Türkiye

E-posta: sandal.semih@gmail.com
Geliş tarihi / Received : : 30.10.2018 Kabul tarihi / Accepted : 19.02.2019 Elektronik yayın tarihi : :14.05.2019 Online published

DOI: $10.12956 /$ tchd.565251 
the study. There were 10 female (76.9\%), 3 male (23.1\%). Female / male ratio was 3.3 and mean age of $12.8 \pm 2.79$ (6-17 years). The mean follow-up period was $8.1 \pm 2.34$ years $(4-13$ years).

At the time of admission, 6 of the patients had rash (46.1\%), 4 had edema in the legs (30.7\%), 2 had swelling and pain in the joints (15.3\%), 1 had chest and joint pain (7.6\%) and 1 had pallor complaint (7.6\%).

In follow-up, 2 patients had skin, 3 had hematological, 5 had joint, 1 had serositis / pericardial and 1 patient had neurological disease involvement. The rate of renal involvement was $84.6 \%$. Three patients had high creatinine levels at admission and 5 patients had nephrotic proteinuria. No correlation was found between proteinuria and creatinine at presentation and histopathological examination.

Conclusion: In this study, SLE, which started in childhood, had more than one system and organ kept at the time of diagnosis. It should be kept in mind that SLE may present with different clinical and laboratory findings in childhood, as morbidity and mortality can be reduced by appropriate diagnosis and treatment.

Key Words: Childhood, Nephritis, Systemic lupus erythematosus

\section{GiRiş}

Sistemik lupus eritematozus (SLE), multisistemik, tanısında otoantikorların belirleyici olduğu, kronik otoimmün bir hastalıktır (1).SLE'de temel patolojinin otoantikorlar, immünkompleksler ve $\mathrm{T}$ lenfositler tarafından oluşturulan doku hasarı olduğu düşünülmektedir. Genetik faktörler ve çevresel faktörlerin de etiyolojide rol oynadığı düşünülmektedir.

Çocuklarda SLE temelde etiyoloji, patogenez, klinik belirtiler ve laboratuvar bulguları ile yetişkinlerle benzerlik gösterse de SLE'li çocuk ve ergenlerin bakımı, hastalığın tedavisinin, fiziksel ve psikolojik büyüme ile gelişim üzerindeki etkisinden dolayı yetişkinlerden farklıdır. Ayrıca böbrek ve nörolojik tutulum erişkinlere kıyasla pediatrik yaş grubunda daha fazladır.

Bu çalışmada SLE tanısı ile izlenen hastaların hastaneye başvuru şikayetlerinin, klinik ve laboratuar bulgularının ve tedavilerinin değerlendirilmesi ayrıca izlem süresince gelişen organ veya sistem tutulumu ve buna yönelik uygulanan tedavilerin değerlendirilmesi amaçlandı.

\section{GEREÇ VE YÖNTEMLER}

Bu çalışma Ocak 2001- Ocak 2014 tarihleri arasında NefrolojiRomatoloji Bölümü tarafından SLE tanısı ile izlenen hastaların dosyaları ve bilgisayar kayıtları geriye dönük incelenerek yapıldı.

Hastaların yaşı, cinsiyeti, başvuru anındaki yakınmaları ve fizik inceleme bulguları, ilaç alım öyküleri kaydedildi. Laboratuvar bulgularından tam kan sayımı, C-reaktif protein (CRP), eritrosit sedimentasyon hızı (ESH), biyokimya tetkikleri (kan üre azotu, kreatinin, AST, ALT, total protein, albümin), tam idrar tetkikleri, 24 saatlik idrar protein düzeyleri, ANA, anti-dsDNA, RF, anti sm-antikorı, antikardiolipin antikorları, antifosfolipid antikorları, C3-C4 düzeyleri, immünglobülinleri (lg), coombs testi, böbrek biyopsisi yapılan hastaların biyopsi sonuçları ve uygulanan tedaviler değerlendirildi.

Çalışmaya Amerikan Romatoloji Birliği'nin (ACR) 1997 yllında yenilediği 11 SLE kriterinden 4 veya daha fazlasını karşılayan ya da böbrek biyopsisi sonucu lupus nefriti ile uyumlu bulgular saptanan 13 hasta (10'u kız, 3'ü erkek) alındı. 4 kriterden daha azını karşılayan, böbrek tutulumu ile başvurup biyopsisi lupus nefritiyle uyumlu olmayan, takibine devam edilemeyen hastalar ve takip süresine bakılmaksızın 22 yaşını dolduran hastalar çalışmadan çıkarıldı.

\section{BULGULAR}

Bu çalışmaya Ocak 2001- Şubat 2014 tarihleri SLE tanısı ile izlenen ve çalışmaya dahil olma kriterlerini karşılayan 13 hasta dahil edildi.

Hastaların ortalama izlem süresi 8.1 \pm 2.34 yıl (4-13 yıl) bulundu. Hastaların 10'u kız (\% 76.9), 3'ü erkek (\% 23.1), kı/erkek

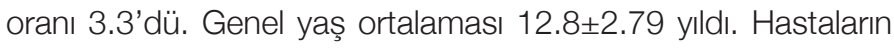
ortalama izlem süresi $8.1 \pm 2.34$ yıldı.

Hastaneye başvuru şikayeti 6'sında (\%46.1) yüzde döküntü, 4'ünde (\%30.7) bacaklarda şişlik, 2'sinde (\%15.3) eklemlerde şişlik ve ağrı, birinde (\%7.6) göğüs ağrısı ve eklem ağrısı, birinde (\%7.6) solukluktu. İzlemde 2 hastada cilt, 3 hastada hematolojik, 5 hastada eklem, 1 hastada serozit/perikard tutulumu, 1 hastada nörolojik tutulum gelişirken iki hasta dışında tüm hastalarda renal tutulum gözlendi (Tablo I).

Başvuru anında hastaların 8'inde (\% 61.5) anemi, 3'ünde (\% 23) trombositopeni, 2'sinde (\% 15.3) lökopeni saptandı. Üç hastada (\% 23) direkt coombs pozitif hemolitik anemi saptandı. Hastaların 5'inde (\%38.4) CRP değeri, 9'unda (\%69.2) ESH referans değerlerin üzerinde bulundu. CRP değeri yüksek olan 4 hastanın 3'ünde enfeksiyonla birliktelik görüldü. ESH yüksek olan hastaların ise 5'inde (\%38.4) aktif hastalık vardı ve 3'ünde major organ tutulumu saptand.

Başvuru anında 3 (\%23) hastada üre yüksekliği, 3 (\%23) hastada kreatinin yüksekliği saptandı. Sekiz hastada (\%61.5) karaciğer fonksiyon testlerinde yükseklik, 7 hastada (\%53.8) hipoalbuminemi saptandı.

Bir hasta hariç diğer hastalarda C3 ve/veya C4 düzeyi düşük saptandı. Bir hasta dışında tüm olgularda antinükleer antikor (ANA) pozitifliği mevcuttu. Bir hastada anti-SS-A antikor pozitifliği, bir hastada antikardiyolipin antikor ve antifosfolipid antikor pozitifliği, üç hastada antikardiyolipin antikor pozitifliği eşlik etmekteydi. Hastaların 12'sinde ANA pozitifliği (\% 92.3), 11 
Tablo I: Hastaların ACR'ye göre SLE kriterleri.

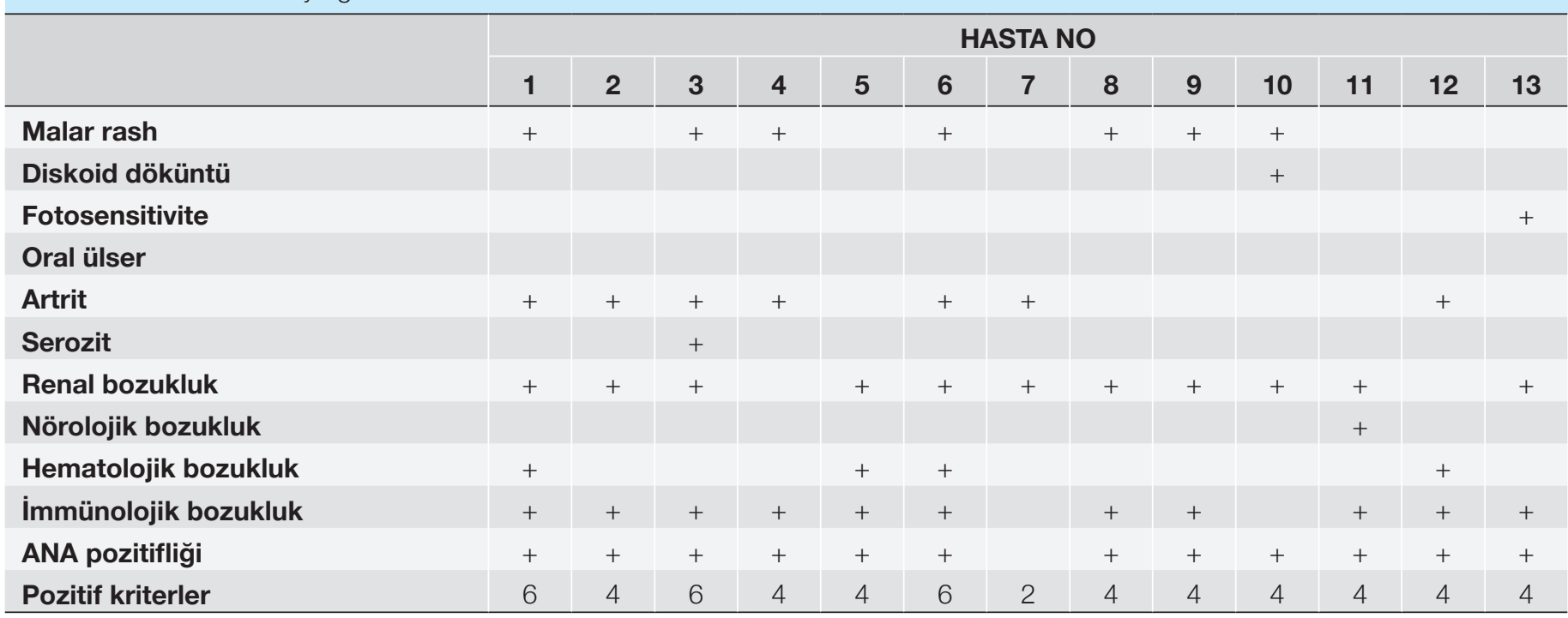

hastada anti-ds DNA pozitifliği (\% 84.6) saptanmıştır (Tablo I).

Böbrek tutulum oranı \% 84.6 olarak bulundu. Üç hastada başvuru anında kreatinin değeri yüksekliği ve 5 hastada nefrotik düzeyde proteinüri saptandı. Hastalara yapılan böbrek biyopsisi sonucunda sadece bir hastada böbrek biyopsisi normal olarak değerlendirildi. Hastaların 7'sinde (\% 53.8) sınıf 2 lupus nefriti, birinde (\% 7.6) sınıf 3 lupus nefriti, 3'ünde (\% 23) sinif 4 lupus nefriti ve birinde (\% 7.6) sınıf 5 lupus nefriti saptandı. Başvuru anındaki proteinüri ve kreatinin ile histopatolojik inceleme sonucu arasında korelasyon yoktu. Hastaların tedavileri böbrek biyopsisi sonuçlarına ve takibinde gelişen sistem tutulumuna göre planlandı. Tablo Il'de hastaların bașvuru anındaki ve izlemdeki klinik bulguları ve uygulanan tedavileri verilmiştir.

Takibimizdeki 13 SLE hastasında 8.1 \pm 2.34 ylllık izlem süresinde mortalite görülmedi.

\section{TARTIŞMA}

Çocuklarda SLE'nin tanı anındaki bulguları çeşitlilik gösterebilir, herhangi bir organ ya da sistem tutulumu söz konusu olabilir $(2,3)$. Bazı çocuklarda akut ve hatta yaşamı tehdit eden belirtiler olmasına rağmen, en sık görülen bașlangıç semptomları, ateş, kilo kaybı ve birkaç ay boyunca genel olarak kötüleșen halsizlik ile bașlayan semptomlarla da kendini gösterebilir. Bu nedenle çoklu organ tutulumu olan her hastada SLE tanısı akla gelmelidir. Destekleyici klinik bulgular yanında başta anti nükleer antikor (ANA) olmak üzere çok sayıda spesifik otoantikor pozitifliği tanı koymada önemlidir.

Çalıșma grubumuz 13 hastadan oluşmaktadır. Bu hastaların ortalama tanı yaşı 12.8 \pm 2.79 (6-17 yll) E/K oranı ise 0.3'tü. Ravelli ve ark.'nın (1) çalışmasında, Amerika, Meksika, Avrupa ve Japonya'daki merkezlerde takip edilen 387 SLE hastasının

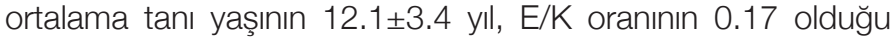
bildirilmiştir. Bunun gibi yapılan birçok çalışma bizim hasta grubumuza benzer şekilde, SLE'nin kIz hastalarda erkek hastalara göre daha baskın olarak görüldüğünü doğrulamıştır. Cinsiyet hormonlarından östrojen, antikor üretimini arttırır, testesteron ise azaltır. SLE'li kIz ve erkek hastalarda östrojen hidroksilasyonunda artma ve östrojenik uyarıya maruz kalma süresindeki uzama, B lenfosit hiperaktivitesine ve çeșitli immünregülasyon anormalliklerine yol açmaktadır.

Nicola ve ark. nın (4) yaptığı çok merkezli metaanaliz çalışmasında 475 SLE'li hastada \% 66.5 oranında ANA pozitifliği, \% 64.1 oranında anti-dsDNA pozitifliği saptandığı bildirilmiștir. Çalıșmada ANA spesifitesi \% 98.8 olarak belirtilirken anti-ds DNA spesifitesi\%97.1 olarak belirtilmiștir. Literatürde ANA titreleri ile renal tutulum arasında ilişki olmadığı, buna karşın artmış anti-ds DNA ve azalmış kompleman seviyeleri ile renal etkilenme arasında ilişki olduğu belirtilmiștir (5). Çalıșmamızda 13 hastanın 12'sinde ANA pozitifliği (\% 92.3), 11 hastada antids DNA pozitifliği (\% 84.6) saptanmıştır. ACR'nin 1997 yllında güncellenen 11 maddelik kllavuzuna alternatif olarak Sistemik Lupus Uluslararası Ișbirliği Klinikleri (SLICC) 2012 ylında yeni bir kılavuz yayınlamıştır. Bu kılavuza göre SLE tanısı koymak için 11 klinik ve 6 immünolojik parametreden bir tanesi immünolojik ve en az bir tanesi klinik olmak üzere 4 kriteri karşılayan veya ANA ya da anti-dsDNA pozitifliği durumunda lupus nefriti ile uyumlu böbrek biyopsisi olması durumunda SLE tanısı konabilmektedir. Yapılan pediatrik popülasyon araştırmalarına göre ACR kriterleri \% 76.6 sensitivite ve \% 93.4 spesifiteye sahipken SLICC kriterleri (Systemic Lupus International Collaborating Clinics) \% 98.7 sensitivite ve \% 85.3 spesifiteye sahip olduğu bulunmuştur. Her ne kadar SLICC kriterleri tanı koymak için hasta ve klinisyenin ANA ve anti-dsDNA bağımlilığını kısmen ortandan kaldırsa da ACR kriterlerinin SLICC kriterlerine kIyasla pediatrik hastalarda daha yararlı olduğu görüşü hâkimdir (6). Pediatrik hastalarda 
Tablo II: Hastaların başvuru anında ve izlemindeki klinik bulgular ve tedavileri.

\begin{tabular}{|c|c|c|c|c|}
\hline Hasta No & $\begin{array}{c}\text { Başvuru anındaki sistem } \\
\text { tutulumu }\end{array}$ & $\begin{array}{c}\text { Böbrek } \\
\text { biyopsisi }\end{array}$ & $\begin{array}{c}\begin{array}{c}\text { İzlem sürecinde olan sistem } \\
\text { tutulumu }\end{array} \\
\end{array}$ & Tedavi \\
\hline 1 & $\begin{array}{c}\text { Kas-iskelet/Cilt/ Hematolojik/ } \\
\text { Renal }\end{array}$ & Sinif 4 & $\begin{array}{l}\text { Hematolojik/Cilt } \\
\text { Renal/ } \\
\text { Kas-iskelet }\end{array}$ & $\begin{array}{c}\text { PMP } \\
\text { Prednisolon } \\
\text { Siklofosfamid } \\
\text { Hidroksiklorakin }\end{array}$ \\
\hline 2 & Renal & Sinif 4 & Renal/ Kas-iskelet & $\begin{array}{c}\text { PMP } \\
\text { Prednisolon } \\
\text { Siklofosfamid } \\
\text { Azotiopürin } \\
\text { Mikofenolatmofeti } \\
\text { Hidroksiklorakin } \\
\text { Rituximab }\end{array}$ \\
\hline 3 & Kas-iskelet / Cilt & Sinif 2 & $\begin{array}{c}\text { Kas-iskelet/ Cilt/ Kardiovasküler/ } \\
\text { Renal }\end{array}$ & $\begin{array}{l}\text { Prednisolon } \\
\text { Siklofosfamid } \\
\text { Hidroksiklorakin } \\
\text { Azotiopurin }\end{array}$ \\
\hline 4 & Kas-iskelet/Cilt & Sinif 2 & Kas-iskelet/ Cilt & $\begin{array}{l}\text { Prednisolon } \\
\text { Siklofosfamid } \\
\text { Hidroksiklorakin } \\
\text { Azotiopürin }\end{array}$ \\
\hline 5 & Hematolojik & Sinıf 2 & Renal/ Hematolojik & $\begin{array}{c}\text { PMP } \\
\text { Prednisolon } \\
\text { Mikofenolatmofeti } \\
\text { Hidroksiklorakin }\end{array}$ \\
\hline 6 & Hematolojik/Kas-iskelet & Sinif 3 & $\begin{array}{l}\text { Hematolojik/ } \\
\text { Kas-iskelet/Renal/ Cilt }\end{array}$ & $\begin{array}{c}\text { PMP } \\
\text { Prednisolon } \\
\text { Hidroksiklorakin }\end{array}$ \\
\hline 7 & Renal & Sinif 2 & Renal/ Kas-iskelet & $\begin{array}{c}\text { PMP } \\
\text { Prednisolon } \\
\text { Hidroksiklorakin }\end{array}$ \\
\hline 8 & Cilt & Sinif 2 & Cilt/ Renal & $\begin{array}{c}\text { PMP } \\
\text { Prednisolon } \\
\text { Siklofosfamid } \\
\text { Hidroksiklorakin } \\
\text { Azotiopurin }\end{array}$ \\
\hline 9 & Cilt & Sinif 2 & Cilt/ Renal & $\begin{array}{c}\text { PMP } \\
\text { Prednisolon } \\
\text { Hidroksiklorakin }\end{array}$ \\
\hline 10 & Cilt & Sinıf 2 & Cilt/ Renal & $\begin{array}{c}\text { PMP } \\
\text { Prednisolon } \\
\text { Siklofosfamid } \\
\text { Azotiopurin } \\
\text { Hidroksiklorakin }\end{array}$ \\
\hline 11 & Renal & Sinif 4 & Renal/ Nörolojik & $\begin{array}{c}\text { PMP } \\
\text { Prednisolon } \\
\text { Siklofosfamid } \\
\text { Hidroksiklorakin }\end{array}$ \\
\hline 12 & Hematolojik/ Kas-iskelet & Normal & $\begin{array}{l}\text { Hematolojik/ } \\
\text { Kas-iskelet }\end{array}$ & $\begin{array}{c}\text { PMP } \\
\text { Prednisolon } \\
\text { Hidroksiklorakin }\end{array}$ \\
\hline 13 & Renal/Cilt & Sinıf 5 & Renal/ Cilt & $\begin{array}{c}\text { PMP } \\
\text { Prednisolon } \\
\text { Siklofosfamid } \\
\text { Azotiopürin } \\
\text { Hidroksiklorakin }\end{array}$ \\
\hline
\end{tabular}


aile öyküsü, yaş, semptomların süresi ve bulguların gelişmesi gibi diğer faktörler, bir çocuğun SLE olarak sınıflandırılmasından önce dikkate alınmalıdır, çünkü SLE'nin sınıflandıııması için klinik veya immünolojik kriterlerin hiçbiri hastalığa özgü değildir. Bazı pediatrik hastalarda sınıflandırma kriterlerini yerine getirmeden lupusa bağlı ciddi organ tutulumu olabilir ve başka kriterlerin gelişmesini beklemeden acilen tedavi edilmelidir. Çalışmamızda başvuru anında SLICC veya ACR'ye göre hiçbir hastaya SLE tanısı konulamamış ancak izlemlerinde immünolojik ve/veya klinik bulguların eklenmesi veya böbrek biyopsisi sonucu tanı konulabilmiştir. Sistemik lupus eritematozusta aktif hastalığı yüksek ESH, düşük kompleman düzeyleri, pozitif ANA ve antids DNA göstermektedir. Anti-ds DNA başvuru anında negatif bulunan 7.12 numaralı hastaların böbrek biyopsi sonuçlarına baktığımızda, hastaların birinde normal, birinde ise sınıf 2 böbrek tutulumu olduğu görülmüş, otoantikorun negatifliği böbrek tutulumunun hafif olması ve/veya olmaması ile ilișkilendirilmiştir. 7 numaralı hastanın izlemi sırasında Anti-dsDNA pozitif olduğu saptanmışıı. Hastalarımızda da anti-dsDNA'nın negatif olması ile hafif renal etkilenme arasındaki ilişki gösterilebilmiştir.

Sistemik lupus eritematozusda artmış otoantikor üretimi vardır. Oluşan antijen-antikor kompleksleri nedeniyle SLE'nin aktif dönemlerinde kompleman aktivasyonuna bağlı olarak C3 ve C4 düşer. Garin EH ve ark.'nın (7) yaptığı 18 SLE nefritini kapsayan çalsşmada C3 düzeyinin SLE nefritinin progresyonu ile ilişkili olduğu, C4 düzeyinin ise ilişkili olmadığı gösterilmiştir. Çalışmamızda da 10 (böbrek biyopsisi sınıf 2) ve 12 (böbrek biyopsisi normal) numaralı hastalar hariç diğer hastaların C3 düzeyleri normalin altında bulunmuştur. Öte yandan böbrek biyopsisi sınıf 4 ve 5 olan hastaların (1, 2, 11 ve 13 numaralı) tümünde C3 düzeyleri normal sınıların altındaydı. C3 düzeyi hem tanı da hem de hastaların tedaviye yanııını izlemede kullanılması gereken önemli bir belirteçtir. Çalışmamızdaki hastaların izlemlerinde son kontrollerinde kullanilan immünsupresif tedavinin etkisi ile klinik basklanmayla beraber C3 düzeylerinde düzelme, 8 ve 11 numaralı hasta hariç, tüm hastalarda görülmüştür.

Sistemik lupus eritematozusda hastaların \% 50-75'inde anemi, trombositopeni ve lökopeni görülür. ACR'ın tanı kriterini yalnızca coombs pozitif hemolitik anemi karşlamaktaysa da hem normokrom normositik anemi hem de mikrositik hipokromik anemi SLE'li hastalarda daha sık olarak görülmektedir. Çalışma grubumuzdaki 5 hastada da coombs pozitif hemolitik anemi dışı nedenlerle anemi geliştiği görülmektedir. Trombositopeni \% 30-45 hastada saptanır ve SLE tanısı konulmadan önce de bulunabilir. Anemi ve/veya kronik trombositopeni olan tüm çocuklar ve adolesanlarda SLE tanısı göz önünde tutulmalıdır (8). Hastalarımızdan da 3'ünde (\%23) direkt coombs pozitif hemolitik anemi, 8'inde (\%61.5) anemi, 3'ünde (\%23) trombositopeni, 2'sinde (\% 15.3) lökopeni saptandı.

Sistemik lupus eritematozusda artralji ve artrit sıklıkla karşılaşılan klinik olgulardandır. Bu yaş grubunda daha sık görülen jüvenil romatoid artritten farklı olarak lupus artriti eklemde kalıc hasar oluşturmaz. Hastaların \% 90'ında hem büyük hem küçük eklemleri tutan poliartiküler artrit olur. Çalışmamızda, tanı anında olmasa da, izlemlerinde 2 hastada artrit saptandı (\% 15.3). Bu iki hastanın artriti deformite bırakmadan kısa sürede nonsteroid antiinflamatuvar ilaçlara yanıt verdi. Hastalarımızın SLE alevlenmesini engelleyen hidroksiklorakinin kullanımının da kas iskelet sistemi bulgularını baskıladığı bilinmektedir. Tüm SLE'li hastalarımızın bu ilacı kullanması hasta grubumuzda literatüre göre daha az artritin ortaya çıkmasına yol açmıştır.

Sistemik lupus eritematozusta böbrek tutulumu mobidite ve mortalitenin belirleyicilerindendir ve hastaların \%80'inden fazlası çocukluk döneminde etkilenir (9). Çocukluk çağı SLE hastalarının \% 50'sinde nefrit görülmekte, bunların \% 80-90'ında bulgular tanının ilk ylında ortaya çıkmaktadır. SLE'li hastalarda renal tutulum görülme oranı $\% 56$, literatürde bu oran bazı kaynaklarda \%50 bazılarında \% 65 olarak bildirilmektedir (10).

On üç SLE tanılı hastamıza yaptığımız böbrek biyopsisi sonucunda sadece bir hastada böbrek biyopsisi normal olarak değerlendirildi. Hastaların 7'sinde (\% 53.8) sınıf 2 lupus nefriti, birinde (\% 7.6) sınıf 3 lupus nefriti, üçünde (\% 23) sınıf 4 lupus nefriti ve birinde (\% 7.6) sınıf 5 lupus nefriti saptandı. Böbrek tutulum oranı \% 84.6 olarak bulundu. 3 hastada başvuru anında kreatinin değeri yüksekliği ve 5 hastada nefrotik düzeyde proteinüri saptandı. Başvuru anındaki proteinüri ve kreatinin ile histopatolojik inceleme sonucu arasında korelasyon yoktu. Sonuç olarak, hasta grubumuzda da, laboratuar bulgularının böbrek biyopsisindeki nefrit sınıflandırmasının ağırlığını tam olarak yansıtmadığı gösterilmişsir, laboratuvardan ziyade böbrek biyopsi bulguları tedavi seçiminde belirleyici olmaktadır.

Son yıllarda gelişen teknoloji ve hastalığın hafif formlarının erken tanınması, tedavide uygun ilaçların kullanıması prognozu olumlu yönde etkilemiştir. Sağ kalım ilk 10 yılda \% 96-98 olmasına rağmen genel populasyona göre risk $2-5$ kat artmış görülmektedir (11). Takibimizdeki 13 SLE hastasında 8.1 \pm 2.34 ylllık izlem süresinde mortalite görülmemiştir.

Sonuç olarak çocukluk çağında başlayan SLE'de tanı anında birden fazla sistem ve organ tutulumu olabilmekte başvuru şikayetleri değişkenlik gösterebilmektedir. Erken tanı ve tedavi ile morbidite ve mortalite azaltılmaktadır. Çocukluk çağında tanı anında SLE'nin farklı klinik ve laboratuvar bulgularıyla karşımıza gelebileceği akılda tutulmalıdır.

\section{KAYNAKLAR}

1. Ravelli A,Duarte-Salazar C, Buratti S, Reiff A, Bernstein B, Maldonado-Velazquez MR, et al. Arthritis Rheum 2003;15:501-7

2. Lehman TJ. Systemic lupusery thematosus in children and adolescents. In: Dubois' Systemic Lupus Erythematosus, 5th ed, Wallace DA, Hahn B (Eds), WB Saunders, Philadelphia 1996.

3. Stichweh D, Arce E, Pascual V. Update on pediatric systemic lupus erythematosus. Curr Opin Rheumatol 2004;16:577. 
4. Bizzaro N, Villalta D, Giavarina D, Tozzoli R. Are anti-nucleosome antibodies a better diagnostic marker than anti-dsDNA antibodies for systemic lupus erythematosus? A systematic review and a study of metanalysis. Autoimmun Rev 2012;12:97-106.

5. Vangelista A, Stipo L, Canova C, Frascà GM, lannelli S, NanniCosta A, Bonomini V. Lupus nephritis: the value of biochemical and immunological monitoring of disease activity. Ren Fail 1996;18:755-63.

6. Textbook of Pediatric Rheumatology 7th edition, sectionthree, systemic connectivet issue diseases 2016;285-448.5

7. Garin EH, Donnelly WH, Shulman ST, Fernandez R, Finton C, Williams RL, et al. The significance of serial measurements of serum complement C3 and C4 componentsand DNA binding capacity in patients with lupus nephritis. Clin Nephrol 1979;12:148-55.
8. Schmugge M, Revel-Vilk S, Hiraki L, Rand ML,Blanchette VS, Silverman ED. Thrombocytopenia and thromboembolism in pediatric systemic lupus erythematosus.J Pediatr 2003;143:6669.

9. Lehman TJ. Systemic lupusery thematosus in children and adolescents. In: Dubois' Systemic Lupus Erythematosus, 5th ed, Wallace DA, Hahn B (Eds), WB Saunders, Philadelphia 1996.

10. Hiraki LT, Benseler SM, Tyrrell PN, Hebert D, Harvey E, Silverman ED. Clinical and laboratory characteristics and long-termoutcome of pediatric systemic lupus erythematosus: a longitudinal study. J Pediatr 2008;152:550-6.

11. Tektonidou MG, Lewandowski LB, Hu J, Dasgupta A, Ward MM. Survival in adults and children with systemic lupus erythematosus: a systematic review and Bayesian meta-analysis of studies from 1950 to 2016. Ann Rheum Dis 2017;76:2009-16. 